\title{
Lymphocyte subsets at different stages of subacute sclerosing panencephalitis: a study with monoclonal antibodies
}

\author{
MARIA GIOVANNA MARROSU, CARLO CIANCHETTI, MARIA GRAZIA ENNAS
}

From the Institute Neuropsichiatria Infantile, University of Cagliari, Italy

SUMMARY Lymphocyte subsets in cerebrospinal fluid (CSF) and peripheral blood were studied using monoclonal antibodies, in patients with subacute sclerosing panencephalitis, eight of whom were at stage 2 and seven at stage 4 . Eighteen subjects affected with non immunological diseases constituted the controls. Regardless of the stage, patients with subacute sclerosing panencephalitis had lower percentages of OKT3 + (pan-T) cells in both CSF and peripheral blood, with an increase of OKIa + cells (B cells, macrophages and active $\mathrm{T}$ cells) in peripheral blood. A difference was found in the proportion of OKT4 + (helper-inducer) and OKT8 + (suppressor/cytotoxic) cells in relation to the stage, the most striking finding being a significant decrease of OKT + with an increase of $\mathrm{T} 4 / \mathrm{T} 8$ ratio in peripheral blood at an early stage.

The persistence of virus-infected cells in the central nervous system (CNS), in spite of high levels of serum and cerebrospinal fluid (CSF) antibodies to measles antigens, suggests that the immune system might be involved in the pathogenesis of subacute sclerosing panencephalitis. ${ }^{12}$ We have studied lymphocyte subpopulations in CSF and peripheral blood from patients with subacute sclerosing panencephalitis. ${ }^{34}$ The percentages of all $\mathrm{T}$ lymphocytes (identified as E-rosette forming cells, E-RFC) and of T lymphocytes bearing IgG Fc receptors (identified as EArosette forming cells, EA-RFC, or TG cells, or "suppressors"), which represent the majority of lymphocytes in the CSF from subjects affected with "non immunological diseases" (NID), were found to be significantly lower in patients with subacute sclerosing panencephalitis. ${ }^{34}$ We recently investigated the antigenic phenotype of CSF lymphocytes using monoclonal antibodies. ${ }^{5}$ These studies showed that in non immunological diseases (a) $90 \%$ of CSF cells

\footnotetext{
Address for reprint requests: Prof. Maria Giovanna Marrosu MD Neuropsichiatria Infantile, Università via Ospedale 119 I-09100 Cagliari, Italy
}

Received 25 June 1985 and in revised form 7 October 1985. Accepted 20 October 1985 were $\mathrm{T}$ lymphocytes, as they reacted with $\mathrm{OKT} 3$, and (b) about $30 \%$ were $\mathrm{T}$ suppressor cells, identified by OKT8, that is a much lower percentage than that of TG cells.

We now report our findings regarding: (a) the evaluation of CSF lymphocyte subsets in patients with subacute sclerosing panencephalitis by monoclonal antibodies, and (b) the comparison of immunological parameters in patients at early and late stages of the disease.

\section{Material and method}

Patients Twelve patients affected with subacute sclerosing panencephalitis (seven males and five females, mean age 9 , range 4-12 years) were studied. Diagnosis was based on clinical, electroencephalographic and laboratory (serum and CSF antimeasles antibody titre, CSF IgG content and CSF protein electrophoresis) findings. CSF cell content was in the normal range in all cases $\left(0.6-6 / \mathrm{mm}^{3}\right)$. Eight patients were studied at clinical stage (according to Jabbour et $a l^{5}$ ), 14 days to 5 months (mean 1.8 months) after the first signs of the disease. Seven patients (three of whom had already been studied at stage 2) were studied at clinical stage 4 , from 4 to 75 months (mean 23.5 months) after the onset of subacute sclerosing panencephalitis. All the latter had been treated for a period of 7-65 (mean 13.7) months with inosiplex. Thymostimuline was administered to three of them for a short period several months before the date of the immunological 
examinations. No patient at stage 2 was treated. Eighteen subjects (nine males and nine females, mean age 27, range 4-52 years), affected with non immunological diseases, were studied as controls: eight were affected with epilepsy, four with spondylotic myelopathy, three with neurosis and three with hydrocephalus.

CSF and peripheral blood lymphocytes Cells were obtained according to the method previously described. ${ }^{6}$

Monoclonal antibodies. OKT3 (all-T), OKT4 (T helperinducer), OKT8 (T suppressor-cytotoxic), OKIa (DR framework: B cells, macrophages and some activated $T$ cells) were purchased from Ortho Diagnostic System (USA). The indirect fluorescence method $^{7}$ was followed.

\section{Results}

Data on mononuclear cells identified in CSF and peripheral blood from subacute sclerosing panencephalitis and non immunological diseases patients are shown in the table. Significant findings in all the patients with subacute sclerosing panencephalitis are: (a) a lower percentage of OKT3 + cells in both CSF and peripheral blood, of OKT4 + cells in CSF and of OKT8 + cells in peripheral blood; (b) an increased percentage of OKIa + cells in peripheral blood. The comparison between patients at stage 2 and 4 shows: (a) in CSF, a lower percentage of OKT8 + cells in stage 4; (b) in peripheral blood, a lower percentage of OKT8 + cells with increased T4/T8 ratio in stage 2 and reduced OKT4+ cells in stage 4.

\section{Discussion}

The evaluation of CSF and peripheral blood lymphocytes using monoclonal antibodies OKT3 in patients with subacute sclerosing panencephalitis, compared with patients with non immunological diseases, confirms the decrease in $T$ cells previously observed using the E-rosette method. ${ }^{23}$ Results with EA-RFC, bearing FcIgG receptors and considered to have suppressor capability, ${ }^{8}$ differ slightly from the present finding with OKT8 (a marker of T suppressor cells), since EA-RFC were reduced in both peripheral blood and CSF in subacute sclerosing panencephalitis. ${ }^{23}$ Moreover, percentages of EA-RFC in CSF were always higher than those of OKT8 + cells, in both non immunological diseases and subacute sclerosing panencephalitis patients (it should be remarked that in CSF the percentage of B cells is very low, about $2 \%$; therefore most cells bearing IgG Fc receptors are $\mathrm{T}$; see ref 7). This is probably due to the fact that IgG-Fc receptors (EA rosette method) and OKT8 monoclonal antibodies both identify cells having suppressor capability, but neither marks all of them (reviewed in ref 8).

The behaviour of lymphocyte subsets at different stages of the disease deserves some consideration. The constant decrease of OKT3 + (pan-T) cells appears in some cases to be due mainly to reduced OKT4 + cells (OKT $8+$ being unchanged) and in others to reduced OKT8 + cells. In CSF, the decrease of OKT4 + at stage 2 (OKT $8+$ being unchanged) contrasts with the decrease of OKT8 + at stage 4 , while the contrary occurs in peripheral blood. Findings at stage 4 are not likely to be due to inosiplex treatment, since the drug is not known to have similar effects on lymphocytes.

The reduction in CSF of some cell subsets, unchanged in peripheral blood, might be due either too reduced passage to the CSF or to sequestration? and/or destruction in the CNS. While no data support the possibility of selective reduced passage to the CSF, a selective increase of some lymphocyte sub $-\frac{7}{2}$ populations in CNS is reported in multiple sclerosis 95 and in experimental allergic encephalomyelitis. ${ }^{10}$ The behaviour of CSF lymphocytes in subacute sclerosing panencephalitis might reflect a similar condition: that is, the decrease of OKT4+ cells at stage 2 and of

Table Percentages of cells reacting with monoclonal antibodies from CSF and peripheral blood from patients with subacute sclerosing panencephalitis (SSPE) and from patients affected with non immunological diseases (NID)

\begin{tabular}{|c|c|c|c|c|c|}
\hline & & SSPE stage 2 & SSPE stage 4 & All SSPE cases & $N I D$ \\
\hline 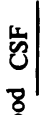 & $\begin{array}{l}\text { OKT3 } \\
\text { OKT4 } \\
\text { OKT8 } \\
\text { T4/T8 }\end{array}$ & $\begin{array}{r}63.9 \pm 14.2(8) \\
43.2 \pm 4.9(4) \\
26.7 \pm 6.8(8) \\
1.9 \pm 0.4(4)\end{array}$ & $\begin{array}{l}78 \cdot 2 \pm 10 \cdot 4(5) \\
17 \cdot 6 \pm 4 \cdot 6(5) \\
-\end{array}$ & $\begin{array}{l}69.4 \pm 14.4(13) \\
43.2 \pm 4.9(4) \\
23.2 \pm 7.4(13) \\
1.9 \pm 0.4(4)\end{array}$ & $\begin{array}{l}89.0 \pm 8.6(18) \\
60.9 \pm 20.2(9) \\
29.8 \pm 10.3(15) \\
2.0 \pm 0.9(9)\end{array}$ \\
\hline 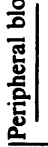 & $\begin{array}{l}\text { OKT3 } \\
\text { OKT4 } \\
\text { OKT8 } \\
\text { T4/T8 } \\
\text { OKIa }\end{array}$ & $\begin{array}{c}58.0 \pm 18.9(8) \\
50.7 \pm 11.5(7) \\
14.7 \pm 8.1(8) \\
3.5 \pm 1.7(7) \\
24.4 \pm 10.2(5)\end{array}$ & $\begin{array}{c}55.2 \pm 12.6(8) \\
38.2 \pm 12.1(8) \\
23.1 \pm 5.7(8) \\
1.7 \pm 0.4(8) \\
20.8 \pm 10.7(5)\end{array}$ & $\begin{array}{c}56.6 \pm 15.6(16) \\
44.0 \pm 13.1(15) \\
18.9 \pm 8.0(16) \\
2.5 \pm 1.5(15) \\
22.6 \pm 10.1(10)\end{array}$ & $\begin{array}{r}71.9 \pm 7.5(17) \\
50.4 \pm 8.2(17) \\
28.8 \pm 9.4(17) \\
1.7 \pm 1.5(17) \\
13.7 \pm 6.7(17)\end{array}$ \\
\hline
\end{tabular}

Percentages of cells reacting with monoclonal antibodies, mean \pm standard deviation (number of cases in brackets).

Statistically significant differences (Student's $t$ test: ${ }^{*}=p<0.05, \uparrow=p<0.01, \ddagger=p<0.001$ ); All SSPE vs NID: CSF T3 $\downarrow *$, T4*; PB T3 + , T8t, Ia*.

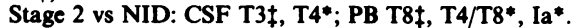

Stage 4 vs NID: CSF T3*, T8t; PB T3†, T4*.

Stage 2 vs stage 4: CSF T8*; PB T8*, T4/T8* 
OKT8 + at stage 4 might be the result of selective sequestration in the central nervous tissue. The findings in peripheral blood indicate a more generalised change of the cellular immune system in subacute sclerosing panencephalitis. T-cells appear to be on the whole reduced, while Ia + cells (which include B lymphocytes, macrophages and some activated $\mathrm{T}$ cells) increase proportionally. The striking decrease of OKT8 + cells and the consequent increase of the T4/T8 ratio at the early stage of subacute sclerosing panencephalitis may suggest some similarities in the behaviour of the immune response to the acute phases of multiple sclerosis, in which OKT8+ reduction is also reported. ${ }^{11} \mathrm{~A}$ decrease of total $\mathrm{T}$ cells in peripheral blood has also been found by others. ${ }^{1213}$ Moreover, Vainiene et $\mathrm{al}^{13}$ found a progressive decrease in $\mathrm{T}$ cells with FcIgG receptors in patients with a rapid course of subacute sclerosing panencephalitis, while they reported a progressive increase in stable cases. This appears to agree with our results of a progressive increase of OKT8 + cells from the "evolutive" stage 2 to stage 4 , a condition of disease stability.

A few other abnormalities were found in cases of subacute sclerosing panencephalitis, ${ }^{12-14}$ although they were not always correlated with the stage of the disease. The significance of such abnormalities in the immune system needs to be explained. It should be noted that measles virus is found to have a depressing effect on $\mathrm{T}$ cells. ${ }^{1}$ Therefore, it remains to be ascertained whether the decrease in $T$ cells in subacute sclerosing panencephalitis might be simply an epiphenomenon, due to the persistence of such a viral effect, or if it is involved in the pathogenetic mechanism of the disease. Supporting this latter hypothesis is the occurrence of more acute measles encephalitides (measles inclusion body encephalitis), ${ }^{15}$ and of subacute sclerosing panencephalitis ${ }^{16}$ in subjects with marked depression of cellular immunity.

This work was supported by a grant from the Ministero Publica Istrazione, Italy.

\section{References}

${ }^{1}$ Agnarsdottir G. Subacute sclerosing panencephalitis. In: Waterson AP, ed. Recent Advances in Clinical Virology. London: Churchill Livingstone, 1977:21-49.

${ }^{2}$ Manconi PE, Marrosu MG, Cianchetti C, Zaccheo D. Surface markers on lymphocytes from human cerebrospinal fluid. II. Altered patterns in subacute sclerosing panencephalitis. Eur Neurol 1979;19:241-6.
${ }^{3}$ Marrosu MG, Cianchetti C, Tondi M, et al. Lymphocyte subpopulations in blood and cerebrospinal fluid from patients with subacute sclerosing panencephalitis. Acta Neurol Scand 1983;67:55-63.

${ }^{4}$ Marrosu MG, Ennas MG, Murru MR, Marrosu G, Cianchetti C, Manconi PE. Surface markers on lymphocytes from human cerebrospinal fluid. III. Identification by monoclonal antibodies. J Neuroimmunol 1983;5: 325-31.

5 Jabbour JT, Garcia JH, Lemmi H, Ragland J, Duenas DA, Sever JI. Subacute sclerosing panencephalitis. A multidisciplinary study of eight cases. JAMA 1969; 207:2248-54.

${ }^{6}$ Manconi PE, Zaccheo D, Bugiani O, et al. Surface markers on lymphocytes from human cerebrospinal fluid. I. Predominance of $\mathrm{T}$ lymphocytes bearing receptors for Fc segment of IgG. Eur Neurol 1978;17:87-91.

${ }^{7}$ Reinherz EL, Kung P, Goldstein G, Schlossman SF. Separation of functional subsets of human $T$ cells by a monoclonal antibody. Proc Natl Acad Sci USA 1979;76:4061-5.

${ }^{8}$ Moretta L, Moretta A, Canonica GW, Bacigalupo A, Mingari MC, Cerottini JC. Receptors for immunoglobulins on resting and activated human $T$ cells. Immunol Rev 1981;56:141-6.

${ }^{9}$ Traugott U, Reiherz EL, Raine CS. Multiple sclerosis. Distribution of $T$ cells, $T$ cells subsets and Ia positive macrophages in lesion of different ages. $J$ Neuroimmunol 1983;4:201-21.

${ }^{10}$ Hickey WF, Gonatas NK, Kimura H, Wilson DB. Identification and quantitation of $\mathrm{T}$ lymphocyte subsets found in the spinal cord of the Lewis rats during acute experimental allergic encephalomyelitis. $J$ Immunol 1983;6:2805-9.

${ }^{11}$ Bach MA, Tournier E, Phan-Dinh-Tuy T, Chatenaud L, Bach JF, Martin C, Degas JD. Deficient suppressor cells in active multiple sclerosis. Lancet 1980;ii: 1221-2.

${ }^{12}$ Derakhshan I, Massaud A, Foroozanfar N, et al. Subacute sclerosing panencephalitis: clinical and immunological study of 23 patients. Neurology (NY) 1981;31:177-80.

${ }^{13}$ Vainiene M, Czlonkowska A, Korlak J. Subacute sclerosing panencephalitis: influence of the clinical course and treatment with isoprinosine on non-specific cellmediated and humoral immunity. Acta Neurol Scand 1983;67:275-84.

${ }^{14}$ Dhid-Jalbut SS, Abdelnoor AM, Haddad FS. Cellular and humoral immunity in subacute sclerosing panencephalitis. Infect Immun 1981;33:34-40.

${ }^{15}$ Roos RP, Graves MC, Wollmann RL, Chilcote RR, Nixon J. Immunologic and virological studies of measles inclusion body encephalitis in an immunosuppressed host: the relationship to subacute sclerosing panencephalitis. Neurology (NY) 1981;31:1263-70.

${ }^{16}$ Coulter JBS, Balch N, Best PV. Subacute sclerosing panencephalitis after drug-induced immunosuppression. Arch Dis Child 1979;54:640-2. 